\title{
The importance of reduced meat and dairy consumption for meeting stringent climate change targets
}

\author{
Fredrik Hedenus • Stefan Wirsenius • \\ Daniel J. A. Johansson
}

Received: 5 July 2013 / Accepted: 3 March 2014 / Published online: 28 March 2014

(C) The Author(s) 2014. This article is published with open access at Springerlink.com

\begin{abstract}
For agriculture, there are three major options for mitigating greenhouse gas (GHG) emissions: 1) productivity improvements, particularly in the livestock sector; 2) dedicated technical mitigation measures; and 3) human dietary changes. The aim of the paper is to estimate long-term agricultural GHG emissions, under different mitigation scenarios, and to relate them to the emissions space compatible with the $2{ }^{\circ} \mathrm{C}$ temperature target. Our estimates include emissions up to 2070 from agricultural soils, manure management, enteric fermentation and paddy rice fields, and are based on IPCC Tier 2 methodology. We find that baseline agricultural $\mathrm{CO}_{2}$-equivalent emissions (using Global Warming Potentials with a 100 year time horizon) will be approximately $13 \mathrm{Gton} \mathrm{CO}_{2} \mathrm{eq} /$ year in 2070, compared to $7.1 \mathrm{Gton} \mathrm{CO}_{2}$ eq/year 2000. However, if faster growth in livestock productivity is combined with dedicated technical mitigation measures, emissions may be kept to $7.7 \mathrm{Gton} \mathrm{CO}_{2} \mathrm{eq} / \mathrm{year}$ in 2070. If structural

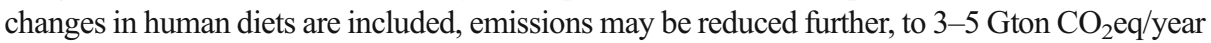
in 2070. The total annual emissions for meeting the $2{ }^{\circ} \mathrm{C}$ target with a chance above $50 \%$ is in the order of $13 \mathrm{Gton} \mathrm{CO}_{2} \mathrm{eq} / \mathrm{year}$ or less in 2070, for all sectors combined. We conclude that reduced ruminant meat and dairy consumption will be indispensable for reaching the $2{ }^{\circ} \mathrm{C}$ target with a high probability, unless unprecedented advances in technology take place.
\end{abstract}

\section{Introduction}

To keep the global average surface temperatures from increasing by more than $2{ }^{\circ} \mathrm{C}$ above the pre-industrial level (UNFCCC 2010), global greenhouse gas (GHG) emissions will have to decrease greatly by the end of this century (Rogelj et al. 2011). However, emissions have yet to peak, and the expected growth in global population and per-capita income will continue to exert a strong upward pressure on emission levels for many decades to come.

In agriculture, several "dedicated," technical options with significant mitigation potential exist, e.g. soil carbon sequestration, increased nitrogen (N)-use efficiency and nitrification inhibitors for reduction of nitrous oxide $\left(\mathrm{N}_{2} \mathrm{O}\right)$ emissions from soils (Snyder et al. 2009; Akiyama et al. 2010; Luo et al. 2010), drainage of paddy rice fields (Fumoto et al. 2010), and

Electronic supplementary material The online version of this article (doi:10.1007/s10584-014-1104-5) contains supplementary material, which is available to authorized users.

F. Hedenus $(\bowtie) \cdot S$. Wirsenius $\cdot$ D. J. A. Johansson

Department of Energy and Environment, Chalmers University of Technology, Gothenburg, Sweden e-mail: hedenus@chalmers.se 
fat additives in ruminant feed rations to reduce methane $\left(\mathrm{CH}_{4}\right)$ (Grainger and Beauchemin 2011). However, it is highly uncertain whether technical measures alone can offer sufficiently deep emission reductions in the long term. In the midterm, the global mitigation potential for $\mathrm{CH}_{4}$ and $\mathrm{N}_{2} \mathrm{O}$ in agriculture through such measures is estimated to be rather small (DeAngelo et al. 2006; Beach et al. 2008; Smith et al. 2008).

Aggregate productivity in the global agricultural sector has increased over time, in particular the past 50 years. This has entailed increased output of crops per unit of land, and meat per unit of feed consumed by livestock. Such productivity increases have also mitigated GHG emissions per unit of food, particularly if land-use-change effects on soil and vegetation carbon stocks are included (Burney et al. 2010). Increased productivity is likely to be a major GHG mitigation option in many low and middle-income countries, where crop yields and feed conversion efficiencies are well below biophysical limits (Lobell et al. 2009; Wirsenius et al. 2010; Tilman et al. 2011; Valin et al. 2013). However, it should also be recognized that yields of wheat and other major crops in some key regions have leveled off and been stagnant in the past 10-20 years (Grassini et al. 2013), which suggests that the potentials for further yield increases are limited. Furthermore, realizing the productivity potentials that do exist will be associated with higher $\mathrm{N}$ turnover per area unit and intensified livestock production, which both may counteract GHG emission reductions.

Dietary changes that substitute vegetable products for animal products may hold a large mitigation potential. However, the actual mitigation level is highly sensitive to which products that are substituted since there is very large variation in the GHG intensity per unit of food within both the animal and vegetable groups (see e.g. Berners-Lee et al. 2012). In addition, a substitution from e.g. meat to vegetables is not consistent with historical and current trends: Per capita consumption of meat continues to increase, also in many affluent countries (FAOSTAT 2013). In most analyses of diets as a mitigation option, assumed dietary changes are not based on specific changes in policy that influence demand (c.f., consumption taxes, as in Wirsenius et al. 2011 and Edjabou and Smed 2013), but instead rely on hypothetical changes in consumer preferences. There is, therefore, poor knowledge of the global mitigation potential through dietary changes under the constraints of consumer preferences.

To our knowledge, no previous study has assessed the combined effect on agricultural GHG emissions of the afore-mentioned mitigation categories increased productivity, technical measures, and dietary changes. Popp et al. (2010) estimated the impact of reducing meat and dairy demand, and Stehfest et al. (2009) found that the cost of reaching stringent climate targets would be significantly lower if consumption of livestock products was abandoned. However, none of these studies included analysis of the mitigation effect of above-baseline increases in agricultural productivity. Valin et al. (2013) carried out analyses of different long-term scenarios of increased productivity, but did not include assessments of the mitigation effect of dedicated mitigation technology or changes (from baseline) in human diets.

This paper aims to contribute to the understanding of global agricultural GHG mitigation by estimating long-term emissions under different mitigation scenarios and relate these emission levels to those compatible with global temperature targets. More specifically, this paper aims to:

1. Assess the global GHG mitigation potential in the agricultural sector from i) livestock productivity increases above baseline; ii) technical measures; and iii) dietary changes from baseline.

2. Assess the compatibility of emissions from the agricultural sector with the $2{ }^{\circ} \mathrm{C}$ target. 


\section{Methods and data}

\subsection{Overview of scenarios and methodology}

In the analysis, we include $\mathrm{CH}_{4}$ from enteric fermentation, paddy rice, and manure management and $\mathrm{N}_{2} \mathrm{O}$ from agricultural soils and manure management. We consider $\mathrm{CO}_{2}$ from fossil fuels to be part of the energy system and not the food system, and it is therefore omitted. We also do not include $\mathrm{CO}_{2}$ from agricultural expansion and other land-use changes. Our methodological approach is purely biophysical and cannot capture the political and socioeconomic mechanisms behind deforestation and land use change.

To analyze future GHG emissions, we construct regionalized food consumption scenarios and calculate the corresponding crop and livestock production in each region. Application rates of $\mathrm{N}$ in fertilizer and manure in crop production are estimated from the $\mathrm{N}$ content in harvested crops and assumptions of $\mathrm{N}$ use efficiencies for different crops and regions. $\mathrm{N}_{2} \mathrm{O}$ from agricultural soils is estimated as an emission factor per mass unit $\mathrm{N}$ input in fertilizer and manure as well as crop residues left on the fields. Feed intake in livestock production is estimated from assumptions on feed energy conversion efficiencies and feed rations for different livestock systems and regions. Based on the feed intake we estimate $\mathrm{N}_{2} \mathrm{O}$ and $\mathrm{CH}_{4}$ from manure excretion and storage, as well as $\mathrm{CH}_{4}$ from enteric fermentation. For details on the scenario assumptions, see the online supplementary material.

We present GHG emission estimates for the years 2000, 2030, 2050 and 2070. The estimate for year 2000 is produced for validation purposes. Our main focus is 2050 and 2070 since the global aggregated emission trajectories to reach the $2{ }^{\circ} \mathrm{C}$ target at a chance more likely than not exhibit substantial emissions reductions by mid-century and beyond. Emissions of $\mathrm{CH}_{4}$ and $\mathrm{N}_{2} \mathrm{O}$ are converted to the $\mathrm{CO}_{2}$-equivalents using the 100-year global warming potential (GWP) that includes indirect climate-carbon cycle feedbacks as reported in Myhre et al. (2013).

We examine five different scenarios (see Table 1) that are partly interlinked. The scenarios are described in more detail in sections 2.2-2.5.

\subsection{Methane and nitrous oxide emissions in the reference scenario}

$\mathrm{N}_{2} \mathrm{O}$ emissions associated with fertilizer and manure application is estimated by calculating the required $\mathrm{N}$ input in crop and pasture production given the $\mathrm{N}$ content in the required biomass output and the $\mathrm{N}$ utilization efficiency of the applied $\mathrm{N}$. The $\mathrm{N}$ efficiency is here defined as the proportion of applied $\mathrm{N}$ that ends up in the above-ground biomass. Regional estimates of $\mathrm{N}$ efficiencies range from $28 \%$ for rice in China (Fan et al. 2009) to about $75 \%$ in forages (Smil 2001; Lenssen et al. 2010). We use data from Cassman et al. (2002), Ladha et al. (2005), and Smil (2001) to estimate current $\mathrm{N}$ efficiencies for different crops in Europe. We then rescale the values for other regions based on Bouwman et al. (2009). The $\mathrm{N}$ efficiency is assumed to improve over time in most regions. In the reference (baseline) scenario, we assume that $\mathrm{N}$ efficiency remains constant in Europe and gradually converges to the European level in North America and Pacific OECD. In other regions, $\mathrm{N}$ efficiency is assumed to be $20 \%$ lower than in Europe by 2050. Direct $\mathrm{N}_{2} \mathrm{O}$ emissions related to fertilizer and manure application were calculated using an emission factor of $1 \% \mathrm{~N}_{2} \mathrm{O}-\mathrm{N}$ per $\mathrm{N}$ applied (IPCC 2006).

$\mathrm{CH}_{4}$ emissions from enteric fermentation is estimated as a fraction of feed intake in energy terms (IPCC 2006), assumed to be $7 \%$ for permanent pasture, $6.5 \%$ for forages (silage/hay), $5 \%$ for protein concentrates and $3.5 \%$ for cereal grains in gross energy terms.

For $\mathrm{N}_{2} \mathrm{O}$ and $\mathrm{CH}_{4}$ from manure management, we estimate the fractions of different manure handling systems in different regions (based on IPCC 2006) and the respective emission 
Table 1 Main characteristics of scenarios to 2070 of global agricultural greenhouse gas emissions

\begin{tabular}{|c|c|c|c|c|}
\hline Scenario & Acronym & Food consumption & Livestock productivity & $\begin{array}{l}\text { Dedicated technical } \\
\text { measures }\end{array}$ \\
\hline $\begin{array}{l}\text { Reference } \\
\text { (baseline) }\end{array}$ & REF & $\begin{array}{c}\text { Based on FAO } \\
\text { projections }\end{array}$ & $\begin{array}{l}\text { Increases in line with } \\
\text { FAO projections }\end{array}$ & None \\
\hline $\begin{array}{l}\text { Increased } \\
\text { productivity }\end{array}$ & IP & As in REF & $\begin{array}{l}\text { Global average feed-to- } \\
\text { product ratio compared } \\
\text { to REF: } \\
\text { - Ruminant meat }+20 \% \\
\text { - Dairy }+50 \% \\
\text { - Other meat }+25 \%\end{array}$ & None \\
\hline $\begin{array}{l}\text { Technical } \\
\text { mitigation }\end{array}$ & $\mathrm{TM}$ & As in REF & As in IP & $\begin{array}{l}\text { - Improved } \mathrm{N} \text { efficiency } \\
\text { - Altered manure } \\
\text { management } \\
\text { - Fat additives to ruminants } \\
\text { - Reduced methane from } \\
\text { rice }\end{array}$ \\
\hline $\begin{array}{l}\text { Climate } \\
\text { carnivore }\end{array}$ & $\mathrm{CC}$ & $\begin{array}{l}75 \% \text { of ruminant meat } \\
\text { and dairy products are } \\
\text { replaced by other meat } \\
\text { (on kcal basis) }\end{array}$ & As in IP & As in $\mathrm{TM}$ \\
\hline Flexitarian & FL & $\begin{array}{l}75 \% \text { of animal food is } \\
\text { replaced by pulses and } \\
\text { cereals (on kcal basis) }\end{array}$ & As in IP & As in TM \\
\hline
\end{tabular}

factors (based on temperature-averages, according to IPCC 2006). Further, from the assumed feed-to-product ratios (Table 2) we estimate the amount of manure produced, which in combination with the assumptions on manure systems are used to estimate $\mathrm{N}_{2} \mathrm{O}$ and $\mathrm{CH}_{4}$ emissions.

\subsection{Livestock productivity scenarios}

Feed requirements are calculated using feed-to-product ratios, here defined as the amount of feed (in gross energy) required to produce one unit of product (in human-metabolizable energy). In addition to the feed-to-product ratio, the feed ration is of great importance for the overall land requirements for animal food production and the associated GHG emissions.

We use two scenarios that reflect different agricultural productivity developments. We construct one Reference (baseline) scenario (REF) and one Increased Productivity scenario (IP). In the REF scenario we assume moderate increases in livestock productivity, largely in line with FAO projections. In the IP scenario we assume faster livestock productivity growth, based on extrapolations from the 'Increased Livestock Productivity' scenario in Wirsenius et al. (2010). Table 2 presents the corresponding estimates of feed-to-product efficiencies.

\subsection{Technical mitigation scenario}

We construct a Technical Mitigation (TM) scenario, based on the IP scenario, where we assess mitigation potentials of different technologies and management practices, and how fast these technologies may be diffused in different regions.

We assume that the $\mathrm{N}$ efficiency in crop production gradually increases so that all regions reach the efficiency level of Europe by 2050. At the global aggregate level, this gives a 
Table 2 Feed-to-product ratios in year 2000 and 2050 for the reference (REF) and increased productivity (IP) scenarios (region acronyms are explained in the supplementary material)

\begin{tabular}{lllllllllll}
\hline MJ GE feed/ MJ ME product & AFR & CPA & EUR & FSU & LAM & MEA & NAM & PAS & SAS \\
\hline Ruminant meat & 2000 & 237 & 99 & 60 & 65 & 155 & 161 & 60 & 148 & 440 \\
& $2050 \mathrm{REF}$ & 189 & 58 & 51 & 53 & 117 & 71 & 51 & 87 & 191 \\
& $2050 \mathrm{IP}$ & 148 & 51 & 51 & 51 & 52 & 51 & 51 & 57 & 153 \\
Dairy bulls & 2000 & 100 & 54 & 23 & 25 & 77 & 52 & 25 & 81 & 198 \\
& $2050 \mathrm{REF}$ & 67 & 32 & 21 & 21 & 48 & 21 & 21 & 48 & 89 \\
& $2050 \mathrm{IP}$ & 63 & 21 & 20 & 20 & 26 & 20 & 20 & 31 & 69 \\
Dairy (whole milk) & 2000 & 47 & 11 & 8 & 12 & 20 & 20 & 7 & 18 & 23 \\
& $2050 \mathrm{REF}$ & 38 & 8 & 7 & 9 & 17 & 10 & 7 & 13 & 20 \\
\multirow{2}{*}{ Other meat } & $2050 \mathrm{IP}$ & 16 & 6 & 5 & 6 & 7 & 7 & 5 & 10 & 8 \\
& 2000 & 16 & 11 & 7 & 9 & 13 & 10 & 7 & 11 & 14 \\
& $2050 \mathrm{REF}$ & 12 & 8 & 7 & 8 & 9 & 8 & 7 & 8 & 9 \\
\hline
\end{tabular}

Data is extrapolated to 2070 by assuming the same relative change as between 2030 and 2050, but with the European level in the 2050 IP scenario as a floor level

reduction in $\mathrm{N}_{2} \mathrm{O}$ emissions of $12 \%$ in 2070 compared to the IP scenario. No additional $\mathrm{N}_{2} \mathrm{O}$ mitigation is assumed. There is a rather large potential for mitigation options for $\mathrm{CH}_{4}$ from paddy rice production. We assume that emissions per $\mathrm{kg}$ rice are gradually abated over time; the abatement starts in 2030 and grows linearly to $80 \%$ reduction by 2070 (Lucas et al. 2007).

We assume that $\mathrm{CH}_{4}$ from enteric fermentation may be reduced by $20 \%$, either by fat additives or other additives in non-pasture feed. We assume that this mitigation option is applied to all ruminant systems in Europe, Pacific Oceania and North America by 2070, and to $50 \%$ of ruminant systems in the rest of the world. We assume a linear interpolation from 2030. This assumption is in line with previous estimates of the mitigation potential for ruminants (DeAngelo et al. 2006; Beach et al. 2008).

Mitigation of manure emissions is arguably most effectively done by using either anaerobic digester or coverage and flaring of methane in slurry systems. Both options reduce $\mathrm{CH}_{4}$ and $\mathrm{N}_{2} \mathrm{O}$ by around $70 \%$ (Montes et al. 2013). There is an even greater $\mathrm{N}_{2} \mathrm{O}$ mitigation potential if solid manure systems are converted to slurry systems. We assume a gradual transition first from solid systems towards slurry systems, and thereafter to slurry systems with flaring. This means that regional aggregate emission factors of $\mathrm{CH}_{4}$ and $\mathrm{N}_{2} \mathrm{O}$ from manure management drop by $30-70 \%$ to 2070 compared to year 2000 .

\subsection{Dietary change scenarios}

We design two scenarios to explore the potential GHG mitigation from dietary changes. In both scenarios we use the TM scenario as a basis. The rationale for this is that substantial deviations from current dietary preferences are unlikely and would probably occur only as a result of policy interventions. However, policy-driven dietary changes are contentious and would almost certainly emerge only after productivity improvements and technical measures largely have been exhausted.

We construct a Climate Carnivore (CC) scenario where $75 \%$ of the ruminant meat and dairy consumption is replaced by other meat (in kcal terms). This scenario represents an increase in total meat by consumption per capita by $45 \%$ compared to the baseline, but the 
average GHG intensity of this meat consumption is lower. We also make a Flexitarian (FL) scenario, where $75 \%$ of all meat and dairy products are replaced by cereals and pulses (in kcal terms). "Flexitarian" is a term assigned to people that often, but not always, choose to eat vegetarian food (Forestell et al. 2012). It should be noted that the degree of substitution of $75 \%$ is not based on any systematic analysis of limiting factors, and should therefore be considered as a tentative basis for an estimate of the upper-end mitigation potential from dietary changes. In addition to the generally conservative nature of food preferences, factors that might limit a far-reaching shift away from meat and dairy consumption include, for example, preservation of landscapes and cultures related to grazing and pastoralism.

\subsection{Emission pathways consistent with $2{ }^{\circ} \mathrm{C}$ stabilization}

To estimate multi-gas emission pathways compatible with the $2{ }^{\circ} \mathrm{C}$ target, we use an integrated climate-economy model based on Johansson (2011). The emission pathways generated in the model represent the least-cost solutions for meeting the temperature target. The emissions of the three most important greenhouse gases $\mathrm{CO}_{2}, \mathrm{CH}_{4}$ and $\mathrm{N}_{2} \mathrm{O}$ are determined endogenously in the model. Abatement of these emissions is modeled by marginal abatement cost functions and with constraints on how rapidly emissions may fall over time. We generate two emission pathways, using two different assumptions on climate sensitivity (being either 3 or $4{ }^{\circ} \mathrm{C}$ for a doubling of the $\mathrm{CO}_{2}$ concentration). Climate sensitivity is defined as the equilibrium increase in the global annual average surface temperature from a doubling of the atmospheric $\mathrm{CO}_{2}$ concentration with respect to pre-industrial levels and its value is likely between 1.5 and $4.5{ }^{\circ} \mathrm{C}$ (IPCC 2013). Climate sensitivity is critical for the emission space compatible with a given climate target. The emission pathway generated with a climate sensitivity of $4{ }^{\circ} \mathrm{C}$ will have a larger chance of keeping the global temperature increase below $2{ }^{\circ} \mathrm{C}$ as compared to the emission pathways generated using a climate sensitivity of $3{ }^{\circ} \mathrm{C}$, see supplementary information for further details.

\section{Results}

\subsection{Emissions per unit of product}

Figure 1a and b present GHG emissions per $\mathrm{kg}$ of product across scenarios and selected regions for ruminant meat and dairy products. The assumed increases in feed efficiency in the baseline scenario explain most of the difference between 2000 and the REF scenario. As can be seen, a substantial reduction in emissions per unit of output can be expected by 2050 in today's low and mid-income regions. However, by assuming faster livestock productivity improvements than in REF, emissions can be reduced even more in IP. In the TM scenario, emissions are reduced even further, but the mitigation effect is less than that achieved by increased livestock productivity.

There are a number of counteracting factors that exert upward pressure on emission levels as feed-to-product efficiencies increase. First, to achieve higher livestock productivity, larger shares of the rations have to consist of energy and protein-rich feed, such as cereals or soybeans. For ruminant systems, the fractions of permanent pasture and crop residues in the ration therefore typically decline as productivity increases. This means that a larger share of the land used for feed production has higher $\mathrm{N}$ fertilizer application rates, which contributes to higher overall $\mathrm{N}_{2} \mathrm{O}$ emissions. The smaller share of pasture-based feed in the rations also means that more manure is produced in stables, which implies higher $\mathrm{CH}_{4}$ emissions from 

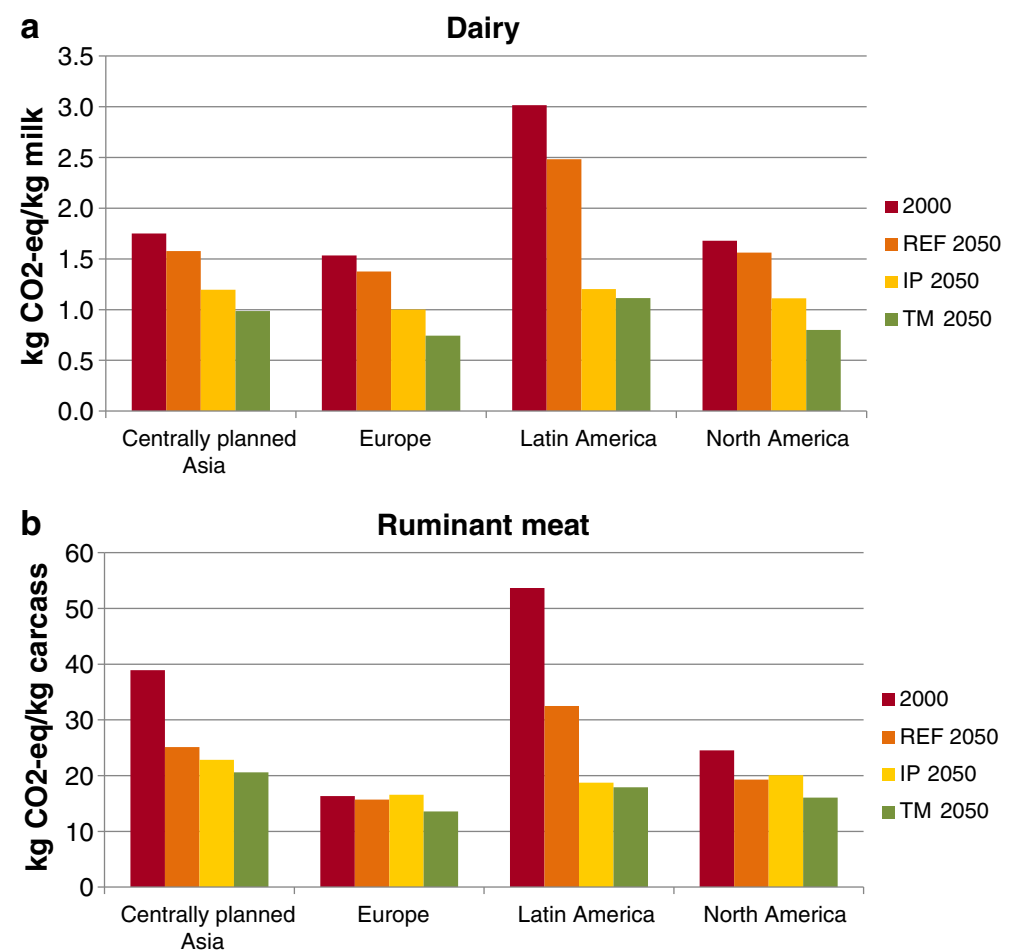

Fig. 1 a Estimated GHG emissions per average unit of output in ruminant meat production in 2000 and scenarios for 2050. (REF Reference, IP Increased productivity, TM Technical mitigation). b Estimated GHG emissions per unit of output in dairy production in 2000 and scenarios for 2050. (REF Reference, IP Increased productivity, TM Technical mitigation)

manure storage facilities. Second, as milk yield in the dairy sector improves, less cattle meat (from surplus dairy calves and culled cows) per unit of milk is produced as a by-product. Most of the GHG emissions from dairy systems may be allocated to the milk output, since it represents roughly $90 \%$ of the milk and meat output in sales value. Therefore, cattle meat from the dairy system may be considered to have lower GHG emissions per unit of meat compared to cattle meat from suckler cow beef systems. Given constant beef demand, this means that the higher the dairy cow milk yield, the higher the average GHG emissions per unit of total beef supply. Similarly, in regions where dairy consumption increases at a slower rate than beef consumption, the share in total beef supply of co-product meat from the dairy sector decreases, and therefore the average emission intensity of ruminant meat increases. These factors are behind the increase in Europe in emissions per unit of ruminant meat in 2050 compared to 2000, see Fig. 2.

\subsection{Emissions from the global food system}

Emissions in the REF scenario amount to 12 Gton $\mathrm{CO}_{2}$ eq in 2050; ruminant meat is responsible for around two thirds and animal products in total for about $80 \%$, see Fig. 2.

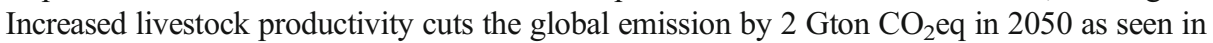
the IP scenario. In the TM scenario, were technical mitigation options are added to the IP scenario the emissions are reduced to about $8.3 \mathrm{Gton} \mathrm{CO}_{2} \mathrm{eq} /$ year in 2050 . The potential for 


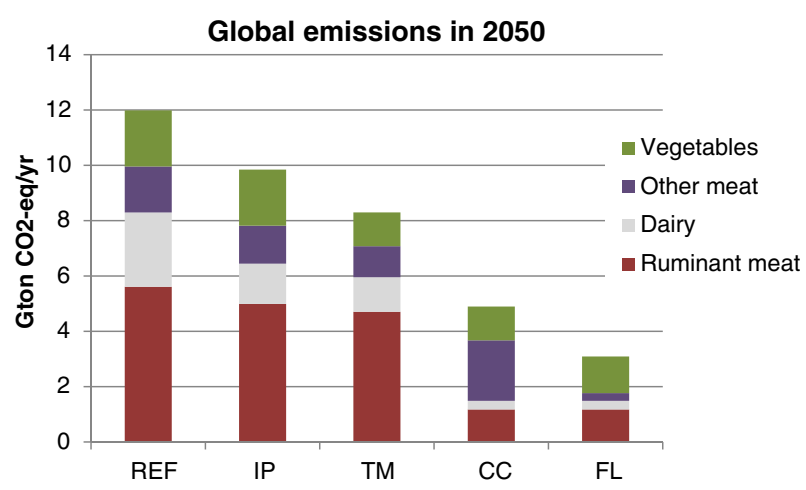

Fig. 2 Global food-related GHG emissions from agriculture in scenarios for 2050. (REF Reference, IP Increased productivity, TM Technical mitigation, CC Climate Carnivore, FL Flexiterian)

productivity improvements and mitigation measures is more restricted in the ruminant sector than for dairy, other meat and vegetables; notice that ruminant meat constitutes a larger fraction of the total emissions in TM than in REF. Changing diets cuts the emissions further, in the $\mathrm{CC}$ scenario the annual emissions are 4.9 Gton $\mathrm{CO}_{2} \mathrm{eq}$, while in the FL scenario the total emissions are about $3.1 \mathrm{Gton} \mathrm{CO}_{2} \mathrm{eq} /$ year. Hence, a radical shift in diets with substantial productivity improvements and technical mitigation measures may cut baseline emissions by about $75 \%$. More detailed data and an uncertainty analysis for each scenario are presented in the supplementary material.

\subsection{Agricultural emissions compared to emission pathways compatible with the $2{ }^{\circ} \mathrm{C}$ target}

The two emission pathways compatible with the $2{ }^{\circ} \mathrm{C}$ target, but based on different assumptions on climate sensitivity, are shown in Fig. 3. The emission pathway generated using the lower climate sensitivity $\left(3{ }^{\circ} \mathrm{C}\right.$ for a $\mathrm{CO}_{2}$ doubling) has about $50 \%$ chance of staying below the temperature target, while the emission pathway generated with the higher sensitivity, gives a higher chance of staying within the limits of the $2{ }^{\circ} \mathrm{C}$ target. ,

As can be seen in Fig. 3, food-related emissions, if they remain unabated, are on track to take up most, if not all, of the long-term annual emission space allowable under the $2{ }^{\circ} \mathrm{C}$ target irrespective of the two emission pathways included here. By 2070 in the REF scenario, foodrelated GHG emissions alone are as high as, or higher than, the annual emissions in either one of the two emission pathways. However, that does not necessarily mean that the $2{ }^{\circ} \mathrm{C}$ target is out of reach; if overall emissions can be cut faster than in our illustrative pathways, this could compensate for higher sustained agricultural GHG emissions in the long-run, see section 4.4 for further discussion.

\section{Discussion}

\subsection{Limitations of data and method}

The approach in this study is bio-physical and does not explicitly include any economic factors. The scenario results presented here should be seen as descriptive rather than predictive. 


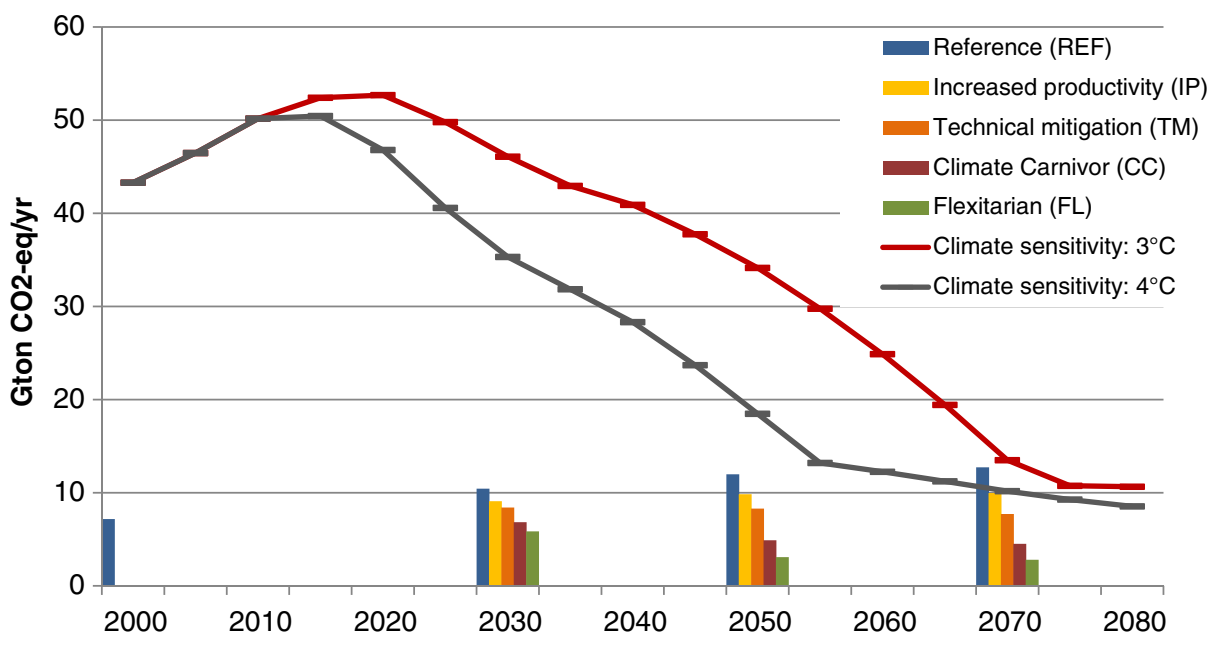

Fig. 3 Emission pathways consistent with the $2{ }^{\circ} \mathrm{C}$ target under different climate sensitivities (lines), and agricultural emissions in the different scenarios for 2030, 2050 and 2070 (bars)

This study excluded some GHG emission sources (see 2.1), most notably $\mathrm{CO}_{2}$ from changes in land use. Plausible levels of long-term $\mathrm{CO}_{2}$ emissions from land-use change span over a wide range, since they depend on several highly uncertain factors. Valin et al. (2013) estimated these at 1.9 billion ton $\mathrm{CO}_{2} /$ year in 2050 in their baseline scenario - this corresponds to about $16 \%$ of total emissions in the REF scenario in this study.

\subsection{Comparison with previous studies}

To make valid comparisons with earlier studies, in this section we use the GWP values reported in Forster et al. (2007) (which were used in earlier studies) instead of Myhre et al. (2013), which were used in this study. Popp et al. (2010) estimated agricultural $\mathrm{CH}_{4}$ and $\mathrm{N}_{2} \mathrm{O}$ emissions in 2055 at about $15 \mathrm{Gton} \mathrm{CO}_{2}$ eq/year in an increased-meatconsumption scenario, and at $10 \mathrm{Gton} \mathrm{CO}_{2}$ eq/year in a scenario with technical mitigation. Corresponding numbers in this study are $10 \mathrm{Gton} \mathrm{CO}_{2} \mathrm{eq} / \mathrm{year}$ (REF scenario) and 8.3Gton $\mathrm{CO}_{2}$ eq/year (TM scenario), respectively. Lack of transparency in Popp et al. (2010) prevents a closer investigation of these differences. The generally lower numbers in our study may be due to lower increases in per-capita meat consumption and/or higher productivity growth in the livestock sector.

In contrast, Valin et al. (2013) produced estimates far lower than those in this study. In their baseline scenario, agricultural $\mathrm{CH}_{4}$ and $\mathrm{N}_{2} \mathrm{O}$ emissions reach about 4.5 Gton $\mathrm{CO}_{2}$ eq/year in 2050, which is less than half of our baseline (REF) scenario, and less than a third of the corresponding scenario in Popp et al. (2010). Different approaches in the modeling of the livestock sector's feed intake and GHG emissions are likely to be the main explanation to these diverging results. This is illustrated by the lower baseyear estimate in Valin et al., which at 3.5 Gton $\mathrm{CO}_{2}$ eq/year (in year 2000) is far lower not only than in this study (5.9 Gton $\mathrm{CO}_{2} \mathrm{eq} / \mathrm{year}$ ), but also in comparison with other studies, including the recent comprehensive FAO study (Gerber et al. 2013), which estimated livestock-related emissions at 5.2 Gton $\mathrm{CO}_{2}$ eq/year. 
4.3 Constraints in long-term emission reductions in the energy and food systems

To meet the $2{ }^{\circ} \mathrm{C}$ target with a probability larger than $50 \%$, global GHG emissions have to drop to about $10 \mathrm{Gton} \mathrm{CO}_{2} \mathrm{eq} / \mathrm{year}$ or less by the second half of this century. The prospects for achieving such very deep emission cuts vary across sectors. As indicated in this study, deep cuts in emissions from food and agriculture do not seem plausible without large changes in consumption towards less GHG intensive food, in particular less ruminant meat and dairy.

Stronger advancement of mitigation technology than that assumed in this study could avoid the assertion that dietary changes may be needed for meeting the $2{ }^{\circ} \mathrm{C}$ target. Our estimates of the potential for technical mitigation of $\mathrm{CH}_{4}$ from ruminants and $\mathrm{N}_{2} \mathrm{O}$ from soils are conservative by design; currently known mitigation technology does not seem to promise large reductions. Moreover, these sources constitute microbe-controlled pathways in the carbon and nitrogen cycles in ruminants and soils, and any use of technology to block such pathways will face the likelihood that microorganisms over time evolve to circumvent blocked pathways. For instance, nitrification (which produces $\mathrm{N}_{2} \mathrm{O}$ as a by-flow) is an exothermic reaction, and therefore represents an energetic potential for soil microorganisms to exploit. It therefore cannot be ruled out that microorganisms would evolve to bypass any pathway blocked through the use of technology such as nitrification inhibitors. On balance, the prospects for deep emission cuts in agriculture through technology seem unfavorable.

Irrespective of the development in the food system, other sectors will need to achieve very large GHG reductions, of the order of $90 \%$ or more, if the $2{ }^{\circ} \mathrm{C}$ target is to be met with a large chance. However, given the substantial constraints for emission reductions in the food system, it might be cost-effective to seek even deeper cuts in other sectors. This applies particularly to energy and transport, for which the prospects for deep reductions by technology are more favorable compared to the food system. However, also in these sectors, technology has limitations, and totally $\mathrm{CO}_{2}$-free systems in 40-50 years from now are imaginable only under optimistic assumptions of technological advancements. More importantly, even if $\mathrm{CO}_{2}$-neutral technologies exist, their diffusion may be a relatively slow process (Wilson 2010).

\subsection{Trade-offs between short and long-lived gases in long-term emission reductions}

The temperature impact of short-lived GHGs (as $\left.\mathrm{CH}_{4}\right)$ and long-lived GHGs $\left(\right.$ as $\left.\mathrm{CO}_{2}\right)$ differ, which has implications for the long-term emission spaces of the different gases. The temperature impact of short-lived gases correlates well with the annual emissions, whereas that of long-lived gases correlates well with the cumulative emissions (Smith et al. 2012). Hence, for a given temperature stabilization level, any change in the cumulative amount of long-lived GHGs emitted will affect the allowable sustained long-run level of emissions of short-lived GHGs. This means that, for a given temperature-increase target, any lowering of the cumulative $\mathrm{CO}_{2}$ emissions will give room for higher sustained emissions of $\mathrm{CH}_{4}$.

This study indicates that, for baseline diets, long-term GHG emissions from the global food system will be dominated by $\mathrm{CH}_{4}$, with a strong link to ruminant meat and dairy consumption levels. Given the trade-off between $\mathrm{CH}_{4}$ and $\mathrm{CO}_{2}$, in particular its asymmetrical nature with respect to time, society's net influence on the cumulative $\mathrm{CO}_{2}$ emissions will be decisive for the long-term emission space of $\mathrm{CH}_{4}$, and hence also for the scope for continued dairy and ruminant meat consumption. Thus, the more cumulative $\mathrm{CO}_{2}$ emissions are depressed, the larger room there will be for perpetual $\mathrm{CH}_{4}$ emissions from ruminants.

In addition to deep cuts in $\mathrm{CO}_{2}$ emissions from the energy and transport systems as discussed above, atmospheric $\mathrm{CO}_{2}$ levels could also be mitigated by technology and management options that sequester atmospheric $\mathrm{CO}_{2}$. One of these is increased carbon sequestration in 
vegetation and/or soils. However, using land for carbon sequestration is likely to compete with food, fiber and bioenergy production. Another option is to use bioenergy together with carbon capture and storage (BECCS), which could in theory offer net negative emissions from the energy system. Such negative emissions could open up the possibility to have larger sustained emissions of $\mathrm{CH}_{4}\left(\right.$ and $\mathrm{N}_{2} \mathrm{O}$ ) for a given temperature target (Azar et al. 2013). However, due to lack hitherto of operational experience, and the inertia in the diffusion of these capital-intensive technologies, the prospect of a full-blown BECCS industry at the scale needed by the second half of the century is highly uncertain.

\section{Conclusions}

This paper indicates that, under current trends, food-related agricultural emissions of $\mathrm{CH}_{4}$ and $\mathrm{N}_{2} \mathrm{O}$ may increase to about $12.7 \mathrm{Gton} \mathrm{CO}_{2} \mathrm{eq} /$ year by the year 2070. This is likely to be larger than the total $\mathrm{CO}_{2}$-equivalent emission level compatible with meeting the $2{ }^{\circ} \mathrm{C}$ limit at chance larger than $50 \%$ (on the order of $10-13 \mathrm{Gton}^{\mathrm{CO}_{2}}$ eq/year or less in 2070). Under policies that favor larger increases in livestock productivity as well as substantial implementation of technical mitigation measures, we estimate that emissions can be kept closer to what is required for the target ( $7.7 \mathrm{Gton} \mathrm{CO}_{2} \mathrm{eq} /$ year). However, only by also assuming reduced meat and dairy consumption do we find agricultural emission levels that do not take more than half of the total emissions space in 2070 . We therefore conclude that dietary changes are crucial for meeting the $2{ }^{\circ} \mathrm{C}$ target with high probability. This conclusion carries even more weight when one considers that other GHG-emitting sectors, in particular energy, also face significant constraints in achieving very large reductions.

Stronger advancement of technology than assumed in this study could significantly relax the need for dietary changes. This applies to technology for mitigation of $\mathrm{CH}_{4}$ from ruminants and $\mathrm{N}_{2} \mathrm{O}$ from soils, for which assumed potentials in this study were conservative, on the basis that known mitigation technology does not seem to promise large reductions. It also applies to technologies such as BECCS which has the potential to sequester atmospheric $\mathrm{CO}_{2}$ and thereby make room for larger sustained agricultural GHG emissions. However, due to lack of operational experience of BECCS, and the inertia in its diffusion, a full-blown BECCS industry in 40-50 years at the scale needed is unlikely.

Acknowledgments Financial support from E.ON, The Swedish Energy Agency and Carl Bennet AB is gratefully acknowledged. The authors also wish to thank Christian Azar, David Bryngelsson, Christel Cederberg and Paulina Essunger, as well as two anonymous reviewers, for valuable comments and suggestions.

Open Access This article is distributed under the terms of the Creative Commons Attribution License which permits any use, distribution, and reproduction in any medium, provided the original author(s) and the source are credited.

\section{References}

Akiyama H, Xiaoyuan Y, Kazuyuki Y (2010) Evaluation of effectiveness of enhanced-efficiency fertilizers as mitigation options for $\mathrm{N}_{2} \mathrm{O}$ and $\mathrm{NO}$ emissions from agricultural soils: meta-analysis. Glob Chang Biol 16:1837-1846

Azar C, Johansson D, Mattson N (2013) Meeting global temperature targets - the role of bioenergy with carbon capture \& storage (BECCS). Environ Res Lett 8:034004 
Beach RH, DeAngelo BJ, Rose S, Li C, Salas W, DelGrosso SJ (2008) Mitigation potential and costs for global agricultural greenhouse gas emissions. Agric Econ 38(2):109-115

Berners-Lee M, Hoolohan C, Cammack H, Hewitt C (2012) The relative greenhouse gas impacts of realistic dietary choices. Energy Policy 43:184-190

Bouwman AF, Beusen AHW, Billen G (2009) Human alteration of the global nitrogen and phosphorous soil balances for the period 1970-2050. Glob Biogeochem Cycles 23, GB0A04

Burney JA, Davis SJ, Lobell DB (2010) Greenhouse gas mitigation by agricultural intensification. Proc Natl Acad Sci 107(26):12052-12057

Cassman KG, Dobermann A, Walters DT (2002) Agroecosystems, nitrogen-use efficiency, and nitrogen management. AMBIO J Hum Environ 31(2):132-140

DeAngelo B, De la Chesnaye FC, Beach RH, Sommer A, Murray B (2006) Methane and nitrous oxide mitigation in agriculture. Energy J 27:89-108

Edjabou LD, Smed S (2013) The effect of using consumption taxes on foods to promote climate friendly dietsthe case of Denmark. Food Policy 39:84-96

Fan M-S, Zhang F-S, Jiang RF (2009) Integrated nutrient management for sustainable agriculture in China. Proceedings of International Plant Nutrition Colloquium XVI, Department of Plant Sciences, UC Davis

FAOSTAT (2013) The statistical database of the Food and Agriculture Organization (FAO), Rome

Forestell CA, Spaeth AM, Kane SA (2012) To eat or not to eat red meat. A closer look at the relationship between restrained eating and vegetarianism in college females. Appetite 58(1):319-325

Forster PM et al (2007) Changes in atmospheric constituents and in radiative forcing climate change 2007: the physical science. Cambridge University Press, Cambridge

Fumoto T, Yanagihara T, Saito T, Yagi K (2010) Assessment of the methane mitigation potentials of alternative water regimes in rice fields using a process-based biogeochemistry model. Glob Chang Biol 16:1847-1859

Gerber PJ, Steinfeld H, Henderson B, Mottet A, Opio C, Dijkman J, Falcucci A, Tempio G (2013) Tackling climate change through livestock: a global assessment of emissions and mitigation opportunities. Food and Agriculture Organization of the United Nations (FAO), Rome

Grainger C, Beauchemin KA (2011) Can enteric methane emissions from ruminants be lowered without lowering their production? Anim Feed Sci Technol 166(23):308-320

Grassini P, Eskridge KM, Cassman KG (2013) Distinguishing between yield advances and yield plateaus in historical crop production trends. Nat Commun 4:2918

IPCC (2006) 2006 IPCC guidelines for national greenhouse gas inventories vol. 4. Prepared by the National Greenhouse Gas Inventories Programme. Eggleston HS, Buendia L, Miwa K, Ngara T and Tanabe K (eds) IGES, Japan

IPCC (2013) Climate change 2013 - the physical science basis - summary for policymakers, working group I contribution to the fifth assessment report of the Intergovernmental Panel on Climate Change, WMO, UNEP

Johansson DJA (2011) Temperature stabilization, ocean heat uptake and radiative forcing overshoot profiles. Clim Chang 108(1-2):107-134

Ladha JK, Pathak H, Krupnik TS, van Kessel C (2005) Efficiency of fertilizer nitrogen in cereal production: retrospects and prospects. Adv Agron 87:85-156

Lenssen AW, Cash SD, Hatfield PG, Sainju UM, Grey WR, Blodgett SL, Goosey HB, Griffith DA, Johnson GD (2010) Yield, quality and water and nitrogen use of durum and annual forages in two-year rotations. Agron J 104(4):1261-1268

Lobell DB, Cassman KG, Field CB (2009) Crop yield gaps: their importance, magnitudes, and causes. Annu Rev Environ Resour 34:179-204

Lucas PL, van Vuuren DP, Olivier JGJ, den Elzen MGJ (2007) Long-term reduction potential of non-CO2 greenhouse gases. Environ Sci Pol 10:85-103

Luo J, de Klein CAM, Ledgard SF, Saggar S (2010) Management options to reduce nitrous oxide emissions from intensively grazed pastures: a review. Agric Ecosyst Environ 136:282-291

Montes F, Meinen R, Dell C, Rotz A, Hristov NA, Oh J, Waghorn G, Gerber PJ, Henderson B, Makkar HPS, Dijkstra J (2013) SPECIAL TOPICS - mitigation of methane and nitrous oxide emissions from animal operations: II. A review of manure management mitigation options. J Anim Sci 91:5070-5094

Myhre GD et al (2013) Anthropogenic and natural radiative forcing. In: Stocker TF et al (eds) Climate change 2013: the physical science basis. Contribution of working group I to the fifth assessment report of the intergovernmental panel on climate change. Cambridge University Press, Cambridge

Popp A, Lotze-Campen H, Bodirsky B (2010) Food consumption, diet shifts and associated non- $\mathrm{CO}_{2}$ greenhouse gases from agricultural production. Glob Environ Chang 20(3):451-462

Rogelj J, Hare W, Lowe J, Van Vuuren DP, Riahi K, Matthews B, Hanaoka T, Jiang K, Meinshausen M (2011) Emission pathways consistent with a 2_C global temperature limit. Nat Clim Chang 1:413-418

Smil V (2001) Feeding the world: a challenge for the twenty-first century. MIT Press, Cambridge

Smith P et al (2008) Greenhouse gas mitigation in agriculture. Phil Trans R Soc B 363:789-813 
Smith SM, Lowe JA, Bowerman NHA, Gohar LK, Huntingford C, Allen MR (2012) Equivalence of greenhouse-gas emissions for peak temperature limits. Nat Clim Chang 2:535-538

Snyder CS, Bruulsema TW, Jensen TL, Fixen PE (2009) Review of greenhouse gas emissions from crop productions systems and fertilizer management effects. Agric Ecosyst Environ 133:247-266

Stehfest E, Bouwman L, van Vuuren DP, den Elzen MGJ, Eickhout B, Kabat P (2009) Climate benefits of changing diet. Clim Chang 95(1-2):83-102

Tilman D, Balzer C, Hill J, Befort BL (2011) Global food demand and the sustainable intensification of agriculture. Proc Natl Acad Sci 108(50):20260-20264

UNFCCC (2010) Decision 1/CP16: the Cancun agreements: outcome of the work of the ad hoc working group on long-term cooperative action under the Convention United Nations Framework Convention on Climate Change (UNFCCC). UNFCCC document FCCC/CP/2010/7/Add1

Valin H, Havlík P, Mosnier A, Herrero M, Schmid E, Obersteiner M (2013) Agricultural productivity and greenhouse gas emissions: trade-offs or synergies between mitigation and food security? Environ Res Lett 8(3):035019

Wilson C (2010) Growth dynamics of energy technologies: using historical patterns to validate low carbon scenarios. Centre for Climate Change Economics and Policy Working Paper No 42

Wirsenius S, Berndes G, Azar C (2010) How much land is needed for global food production under scenarios of dietary changes and livestock productivity increases in 2030? Agric Syst 103:621-638

Wirsenius S, Hedenus F, Mohlin K (2011) Greenhouse gas taxes on animal food products: rationale, tax scheme and climate mitigation effects. Clim Chang 108(1-2):391-410 